\title{
Global hydrological droughts in the 21st century under a changing hydrological regime
}

\author{
N. Wanders ${ }^{1}$, Y. Wada ${ }^{1}$, and H. A. J. Van Lanen ${ }^{2}$ \\ ${ }^{1}$ Department of Physical Geography, Faculty of Geosciences, Utrecht University, Utrecht, the Netherlands \\ ${ }^{2}$ Hydrology and Quantitative Water Management Group, Centre for Water and Climate, Wageningen \\ University, Wageningen, the Netherlands \\ Correspondence to: N. Wanders (n.wanders@uu.nl)
}

Received: 16 May 2014 - Published in Earth Syst. Dynam. Discuss.: 6 June 2014

Revised: 25 November 2014 - Accepted: 2 December 2014 - Published: 6 January 2015

\begin{abstract}
Climate change very likely impacts future hydrological drought characteristics across the world. Here, we quantify the impact of climate change on future low flows and associated hydrological drought characteristics on a global scale using an alternative drought identification approach that considers adaptation to future changes in hydrological regime. The global hydrological model PCR-GLOBWB was used to simulate daily discharge at $0.5^{\circ}$ globally for 1971-2099. The model was forced with CMIP5 climate projections taken from five global circulation models (GCMs) and four emission scenarios (representative concentration pathways, RCPs), from the Inter-Sectoral Impact Model Intercomparison Project.

Drought events occur when discharge is below a threshold. The conventional variable threshold (VTM) was calculated by deriving the threshold from the period 1971-2000. The transient variable threshold $\left(\mathrm{VTM}_{\mathrm{t}}\right)$ is a non-stationary approach, where the threshold is based on the discharge values of the previous 30 years implying the threshold to vary every year during the 21 st century. The $\mathrm{VTM}_{\mathrm{t}}$ adjusts to gradual changes in the hydrological regime as response to climate change.

Results show a significant negative trend in the low flow regime over the 21st century for large parts of South America, southern Africa, Australia and the Mediterranean. In 40-52\% of the world reduced low flows are projected, while increased low flows are found in the snow-dominated climates.

In $27 \%$ of the global area both the drought duration and the deficit volume are expected to increase when applying the $\mathrm{VTM}_{\mathrm{t}}$. However, this area will significantly increase to $62 \%$ when the VTM is applied. The mean global area in drought, with the $\mathrm{VTM}_{\mathrm{t}}$, remains rather constant (11.7 to 13.4\%), compared to the substantial increase when the VTM is applied (11.7 to $20 \%$ ).

The study illustrates that an alternative drought identification that considers adaptation to an altered hydrological regime has a substantial influence on future hydrological drought characteristics.
\end{abstract}

\section{Introduction}

Drought has large socio-economic and environmental impacts, e.g. on food (rainfed agriculture, irrigation), energy (hydropower, release of cooling water), water-born transport, ecosystem services, wildfires, and greenhouse gas emissions (e.g. Wilhite, 2000; Tallaksen and Van Lanen, 2004; Sheffield and Wood, 2011). The 2011 drought in the Horn of Africa caused a large famine across the region leaving hundreds of thousands of people in need of assistance and with many regrettable fatalities (United Nations, 2011; Sida et al., 2012). Drought-related heat waves and forest fires caused almost 80000 deaths in Europe in 2003. Overall losses were estimated to be about Eur 5000 billion over the period 1998 2009 (EEA, 2010). IPCC describes in the Special Report on EXtremes (IPCC-SREX) that droughts will intensify in the 21 st century in certain seasons and areas (e.g. many European regions, parts of North America, Central America, southern Africa) as result of climate change (Seneviratne et al., 2012). Society needs to be better prepared to ensure 
future water, food and energy security (e.g. Romm, 2011; Van Vliet et al., 2012; Bourzac, 2013). The severe impacts of large-scale droughts show the need to improve understanding of droughts on continental and global scales, particularly to increase credibility of future drought projections.

Drought is induced by below-normal precipitation and/or temperature anomalies, which also propagate to reduce soil moisture. For management of groundwater and surface water, however, more relevant is the further propagation into hydrological drought (e.g. Van Loon and Van Lanen, 2012). Despite the need for hydrological drought information, most large-scale future drought studies focus either on precipitation or soil moisture (e.g. Burke et al., 2006; Sheffield and Wood, 2008; Sheffield et al., 2012; Dai, 2013; Orlowsky and Seneviratne, 2013; Trenberth et al., 2014). Few studies deal with assessments of large-scale future hydrological drought (e.g. Forzieri et al., 2014; Wanders and Van Lanen, 2013; Prudhomme et al., 2014; Wanders and Wada, 2014). The limitation of these studies is, however, that most of them only use one emission scenario that is based on the previous generation (i.e. CMIP3) of global circulation models (GCMs) and the previous scenario projections (i.e. IPCC SRES). Furthermore, Forzieri et al. (2014) only assess future drought for one continent (i.e. Europe) at high spatial resolution, rather than spanning the whole globe. An exception is the recent study by Prudhomme et al. (2014), which describes projections of hydrological drought across the world obtained from a comprehensive multi-model ensemble (five GCMs and seven global hydrological models - GHMs) using most recent climate models (CMIP5) and four emission scenarios (i.e. representative concentration pathways, RCPs). All studies on large-scale future hydrological drought, so far, have used the so-called threshold method (e.g. Hisdal et al., 2004; Fleig et al., 2006), and drought characteristics in the 21st century are identified by using the threshold of the control or historical period (e.g. 1971-2000). However, one may argue whether or not such a stationary approach is suitable for all impact assessments. An updated (transient) threshold for a moving reference period that reflects changes in the hydrological regime over time might be more appropriate to assess such impacts. Vidal et al. (2012) explored the use of a changing drought index for future drought in France. A transient threshold assumes adaptation to long-term changes in the hydrological regime. It is also more in line with the drought definition (Tallaksen and Van Lanen, 2004) being a deviation from normal conditions (i.e. normal implies decadally updated 30-year averages according to the World Meteorological Organization guidelines), although the consequences of such statistically constructed metric for real-world applications need careful investigation (e.g. World Meteorological Organization, 2007; Arguez and Vose, 2010) and should consider whether drought-impacted sectors can cope with the changes in the hydrological regime.

The objective of this study is to assess the impact of climate change on future hydrological drought across the globe under a changing hydrological regime, here represented using a transient threshold over the spatially distributed river discharge. The paper is innovative by using the following: (i) a gradually changing, spatially distributed threshold to adapt to changing hydrological regime, (ii) the latest version of climate models from CMIP5 climate projections, and (iii) the number of emission scenarios: four RCPs $(2.6,4.5$, $6.0,8.5)$.

The paper starts with a brief description of the global hydrological model, forcing data, drought identification approach and the trend analysis, which are followed by the description of the temporal evolution of the spatially distributed threshold for the river discharge over the 21st century. Next, future drought duration and drought intensity obtained with the transient threshold method, reflecting a changing hydrological regime, are presented and intercompared with the non-transient threshold approach that is derived from the control period (fixed historical period). Results are followed by a discussion that intercompares the outcome of this study with existing assessments of future hydrological drought. It also addresses uncertainty aspects (e.g. variability among GCMs and RCPs), sensitivity of the threshold values applied $\left(Q_{80}, Q_{90}\right)$, and the impact of the combined effect of the change in the simulated water availability (hydrological regime) and in the drought characteristics. Eventually, conclusions and a recommendation are given.

\section{Material and methods}

\subsection{Model simulation of streamflow}

The state-of-the-art global hydrological and water resources model PCR-GLOBWB was used to simulate spatial and temporal continuous fields of discharge and storage in rivers, lakes, and wetlands at a $0.5^{\circ}$ spatial resolution (Wada et al., 2010, 2013, 2014; Van Beek et al., 2011). In brief, the model simulates for each grid cell and for each time step (daily) the water storage in two vertically stacked soil layers and an underlying groundwater layer. At the top a canopy with interception storage and a snow cover may be present. Snow accumulation and melt are temperature driven and modelled according to the snow module of the HBV model (Bergström, 1995). To represent rain-snow transition over sub-grid elevation-dependent gradients of temperature, $10 \mathrm{el}-$ evation zones were distinguished in each grid cell based on the HYDRO1k Elevation Derivative Database, and scaled the $0.5^{\circ}$ grid temperate fields with a lapse rate of $0.65^{\circ} \mathrm{C}$ per $100 \mathrm{~m}$. The model computes the water exchange between the soil layers, and between the top layer and the atmosphere (rainfall, evaporation and snowmelt). The third layer represents the deeper part of the soil that is exempt from any direct influence of vegetation, and constitutes a groundwater reservoir fed by active recharge. The groundwater store is explicitly parameterized and represented with a linear reservoir model (Kraijenhof van de Leur, 1962). Sub-grid vari- 
Table 1. GCMs (global climate models) used in this study.

\begin{tabular}{ll}
\hline GCM & Organization \\
\hline HadGEM2-ES & Met Office Hadley Centre \\
IPSL-CM5A-LR & Institute Pierre-Simon Laplace \\
MIROC-ESM-CHEM & JAMSTEC, NIES, AORI \\
& (The University of Tokyo) \\
GFDL-ESM2M & NOAA Geophysical \\
& Fluid Dynamics Laboratory \\
NorESM1-M & Norwegian Climate Centre \\
\hline
\end{tabular}

ability is considered by including separately short and tall natural vegetation, open water (lakes, floodplains and wetlands), soil type distribution (FAO Digital Soil Map of the World), and the area fraction of saturated soil calculated by the Improved ARNO scheme (Hagemann and Gates, 2003) as well as the spatio-temporal distribution of groundwater depth based on the groundwater storage and the surface elevations as represented by the $1 \mathrm{~km}$ by $1 \mathrm{~km}$ Hydrolk data set (https://lta.cr.usgs.gov/HYDRO1K/). Simulated specific runoff from the two soil layers (direct runoff and interflow) and the underlying groundwater layer (base flow) is routed along the river network based on the Simulated Topological Networks (STN30) (Vörösmarty et al., 2000) using the method of characteristic distances (Wada et al., 2014).

The PCR-GLOBWB model and model outputs has been extensively validated in earlier work. Simulated mean, minimum, maximum, and seasonal flow (all at monthly temporal step), monthly actual evapotranspiration, and monthly total terrestrial water storage were evaluated respectively against 3613 GRDC stations (http://www.bafg.de/GRDC) $\left(R^{2} \sim 0.9\right.$ and slope $\sim 0.9$ to 1.1 respectively for each monthly flow), the ERA-40 reanalysis data, and the GRACE satellite observations, in earlier work (Van Beek et al., 2011; Wada et al., 2012, 2014), and generally showed good agreement with them.

In brief, the PCR-GLOBWB model has been evaluated with $R^{2}$, slope and the root mean square error (RMSE) against 3613 GRDC stations with drainage areas larger than $2500 \mathrm{~km}^{2}$, which is roughly equivalent to one grid cell $\left(0.5^{\circ}\right)$. These stations contain the long-term statistics of mean, minimum, and maximum discharge with sufficient data record (more than 10 years of monthly data), to evaluate our modelled streamflow. Because of the coarse spatial resolution of the model $\left(0.5^{\circ}\right)$, the upstream drainage area of some stations, particularly the smaller ones, cannot be represented accurately; thus they have not been included in our model evaluation. Notwithstanding, this data set provides a good starting point to evaluate the skill of the model to simulate discharge variations within and between years for varying catchment sizes and regions. In addition, in Wada et al. (2014), the monthly streamflow has also been evaluated with $R^{2}$, slope, and Nash-Sutcliffe model efficiency coefficient (NSC). We
Table 2. Overview of representative concentration pathways (RCPs) (Van Vuuren et al., 2011). Radiative forcing values include the net effect of all anthropogenic greenhouse gases and other forcing agents.

\begin{tabular}{|c|c|}
\hline $\mathrm{RCP}$ & Scenario \\
\hline 2.6 & $\begin{array}{l}\text { Peak in radiative forcing at } \sim 3.1 \mathrm{~W} \mathrm{~m}^{2} \\
(\sim 490 \mathrm{ppmCO} 2 \text { equivalent }) \\
\text { before } 2100 \text { and then decline (the selected } \\
\left.\text { pathway declines to } 2.6 \mathrm{~W} \mathrm{~m}^{2} \text { by } 2100\right)\end{array}$ \\
\hline 4.5 & $\begin{array}{l}\text { Stabilization without overshoot pathway to } 4.5 \mathrm{~W} \mathrm{~m}^{2} \\
\left(\sim 650 \mathrm{ppm} \mathrm{CO}_{2} \text { equivalent }\right) \\
\text { at stabilization after } 2100\end{array}$ \\
\hline 6.0 & $\begin{array}{l}\text { Stabilization without overshoot pathway to } 6 \mathrm{~W} \mathrm{~m}^{2} \text { at } \\
\left(\sim 850 \mathrm{ppm} \mathrm{CO}_{2} \text { equivalent }\right) \\
\text { stabilization after } 2100\end{array}$ \\
\hline 8.5 & $\begin{array}{l}\text { Rising radiative forcing pathway leading to } 8.5 \mathrm{~W} \mathrm{~m}^{2} \\
\left(\sim 1370 \mathrm{ppmCO}_{2} \text { equivalent }\right) \text { by } 2100\end{array}$ \\
\hline
\end{tabular}

refer to Van Beek et al. (2011) and Wada et al. (2014) for the detailed descriptions of the validation exercises.

The model has also been applied to simulate low flow conditions and associated hydrological drought events at a global scale (Wada et al., 2013), and simulated drought deficit volumes and drought frequency were extensively validated against those derived from observed streamflow (from GRDC stations) (Wada et al., 2013) over regions where drought has a major impact on the hydrology. The comparison showed that the model performance is good for simulating low flow conditions across regions with different climatic conditions. In addition, the model has been tested to simulate different drought conditions using different percentile threshold levels $\left(Q_{70}, Q_{80}\right.$, and $\left.Q_{90}\right)$ and the performance remains good. These previous modelling exercises led to the conclusion that the PCR-GLOBWB model is suited to reproduce low flow conditions and that the model can adequately simulate hydrological drought events across the globe. Uncertainties that are inherent to the model and the intercomparison with existing studies or models are discussed in Sect. 4.

The model was forced with daily fields of precipitation, reference (potential) evapotranspiration and temperature taken from five global climate models (GCMs; see Table 1) and four underlying emission scenarios (here accounted for by using four RCPs; see Table 2). The newly available CMIP5 climate projections were obtained through the Inter-Sectoral Impact Model Intercomparison Project (Warszawski et al., 2014). The GCM climate forcing was bias-corrected on a grid-by-grid basis $\left(0.5^{\circ}\right.$ grid) by scaling the long-term monthly means of the GCM daily fields to those of the observation-based WATCH climate forcing for the overlapping reference climate 1960-1999 (Hempel et al., 2013). Potential evapotranspiration was calculated with the bias-corrected GCM climate forcing with the method of Hamon (1963). The resulting bias-corrected transient daily 
climate fields were used to force the model over the period 1971-2099 with a spin-up, reflecting a climate representative prior to the start of the simulation period. The result of each GCM is treated equally and no weight was given to a particular GCM based on the performance against historic climate. As a result, 20 (five GCMs by four RCPs) projections of future daily streamflow were produced.

\subsection{Drought calculation}

Hydrological drought characteristics (e.g. drought duration and deficit volume) were derived from simulated time series of daily discharge $(Q)$ using the variable threshold level approach (Yevjevich, 1967; Tallaksen et al., 1997; Hisdal et al., 2004). In this study the $Q_{90}\left(\mathrm{~m}^{3} \mathrm{~s}^{-1}\right)$ was derived from the flow duration curve, where the $Q_{90}$ is the threshold which is equalled or exceeded for $90 \%$ of the time. This threshold has been selected to study the impact of severe drought conditions and has been used in multiple studies where drought is studied (e.g Fleig et al., 2006; Parry et al., 2010; Wanders and Van Lanen, 2013).

Similar to Wanders and Van Lanen (2013) the drought state is given by

$\operatorname{Ds}(t, n)=\left\{\begin{array}{ll}1 & \text { for } Q(t)<Q_{x}(t, n) \\ 0 & \text { for } Q(t) \geq Q_{x}(t, n)\end{array}\right.$,

where $Q_{x}(t, n)$ is the $x$ percentile threshold, and $\operatorname{Ds}(t, n)$ is a binary variable indicating whether a location or grid cell $(n)$ is in drought at a given time $t$. The drought duration for each event at $n$ is calculated with

$\operatorname{Dur}_{i, n}=\sum_{t=S_{i}}^{L_{i}} \operatorname{Ds}(t, n)$,

where $\operatorname{Dur}_{i, n}$ is the drought duration $(d)$ of event $i$ at $n, S_{i}$ the first time step of an event $i$ and $L_{i}$ the last time step of the event. The deficit volume per time step was defined by

$\operatorname{Def}(t, n)= \begin{cases}Q_{x}(t, n)-Q(t, n) & \text { for } \operatorname{Ds}(t, n)=1 \\ 0 & \text { for } \operatorname{Ds}(t, n)=0\end{cases}$

where $\operatorname{Def}(t, n)$ is the daily deficit volume of drought $i$ $\left(\mathrm{m}^{3} \mathrm{~s}^{-1}\right)$ at $n$. The total drought deficit volume for each drought event was calculated with

$\operatorname{Def}_{i}(n)=\sum_{t=S_{i}}^{L_{i}} \operatorname{Def}(t, n)$

where $\operatorname{Def}_{i}(n)$ is the total deficit volume of the drought event $i\left(\mathrm{~m}^{3} \mathrm{~s}^{-1}\right)$ at $n$. The deficit volume is the cumulative deviation of the discharge from the threshold over the duration of a drought event. If the $Q_{x}(t, n)$ equals $0 \mathrm{~m}^{3} \mathrm{~s}^{-1}$, by definition a drought will not occur since $\operatorname{Ds}(t, n)$ will remain zero (Eq. 1). If $Q_{x}(t, n)$ equals $0 \mathrm{~m}^{3} \mathrm{~s}^{-1}$ for more than $50 \%$ of the time, no drought characteristics were calculated for this cell. These cells were excluded from the analysis, since frequent zero discharge situations are part of the local climate (i.e. aridity) and are not a manifestation of hydrological drought condition or occurrence (Wanders and Van Lanen, 2013).

The total area in drought (AID) at a given time $t$ was calculated by

$\operatorname{AID}(t)=\frac{\sum_{n=1}^{N} \operatorname{Ds}(t, n)}{N}$,

where $\operatorname{AID}(t)$ is the total area in drought, $N(-)$ is the total number of cells in the area (e.g. continent, Köppen-Geiger climate region) or all grid cells (globe) except those arid regions that were excluded from the analysis. The $\operatorname{AID}(t)$ can range between 0 and 1 , where 0 indicates that there is no cell in the area in drought and 1 indicates that all cells in the area are in drought.

\subsection{Variable threshold approach}

In this study, two variable threshold approaches were used. The first approach uses the non-transient calculation of the variable threshold level method, where monthly values of $Q_{x}$ are calculated from the aggregated daily values of $Q(t)$ over a fixed 30-year period (usually 1971-2000). Thereafter, the monthly values of $Q_{x}$ are smoothed with a moving average window of 30 days, resulting in the conventional variable threshold (VTM, Van Loon and Van Lanen, 2012; Van Lanen et al., 2013; Prudhomme et al., 2014; Van Loon et al., 2014), which was used in the few studies so far on future hydrological drought.

However, present climatology can significantly change over the future period under climate change. This will result in an altered hydrological regime. This could have a significant impact on the detection of drought events, leading to the misrepresentation of drought events as reported by Van Huijgevoort et al. (2014). Areas which become gradually dryer will be constantly in drought, whereas the opposite will happen in regions with increased low flows. Hydrological regime shifts (e.g earlier snowmelt peak) could have a similar impact, where the threshold is not adjusted to the new hydrological conditions. Therefore, we propose the transient variable threshold $\left(\mathrm{VTM}_{\mathrm{t}}\right)$, where monthly values of $Q_{x}$ are calculated from the aggregated daily values of $Q(t)$ of the previous 30 years (Fig. 1). The monthly values of $Q_{x}$ are derived from the discharge climatology of the past 30 years instead of a threshold based on a historic period (1971-2000). The monthly $Q_{x}$ is smoothed with a moving average window of 30 days, resulting in the variable threshold $\left(\mathrm{VTM}_{\mathrm{t}}\right)$.

The difference between the VTM and $\mathrm{VTM}_{t}$ can be seen in Fig. 1. Both thresholds have been applied to the complete time series of river discharges for the period 2000-2099, and drought events were calculated. 


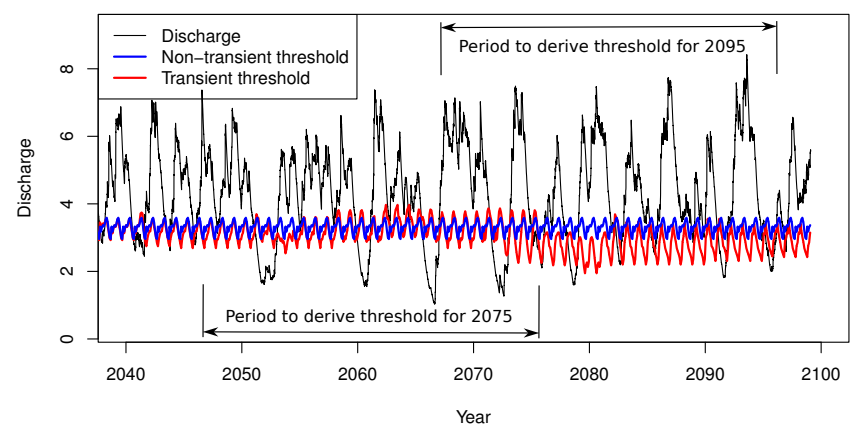

Figure 1. Example time series with schematic overview of the nonstationary variable threshold (VTM), which is constant over the $21 \mathrm{st}$ century, and the stationary variable threshold $\left(\mathrm{VTM}_{\mathrm{t}}\right)$ that considers the gradually changing future hydrological regime.

\subsection{Trend analysis}

To study the trends in future drought thresholds, time series of 130 years of simulated river discharges were used. A linear regression was used to study the directionality of the changes and the robustness of those changes. These analyses were performed for each cell separately to study the effect of regime shifts (e.g due to shifts in snowmelt peaks). The robustness in the spatially distributed trends of the threshold was investigated per season for an ensemble of five GCMs and four RCPs, and only statistically significant $(p<0.05)$ trends were taken into account. For each cell the trend was calculated over the 3 months belonging to the season for each of the 20 ensemble members. If for a certain season 16 out of 20 ensemble members showed the same trend direction, it was assumed to be a robust decrease or increase. If 13 to 15 members had the same direction, then the trend is classified as a possible decrease of increase, while for a lower number than 13 , no trend was supposed to occur.

Relative trends in drought characteristics were determined by comparing the average drought characteristics for the period 1971-2000 to the period 2070-2099. Per year the number of droughts, number of drought days and total drought deficit were calculated. Yearly statistics were used since drought events often last for more than 1 month and therefore it would result in large fluctuations in monthly drought statistics. The robustness in the trends in drought characteristics was studied by comparing the outcome from the multiple GCM simulations for each RCP scenario. If for one RCP all five GCMs pointed in the same direction, it was assumed to be robust, while if the GCMs showed more discrepancy the changes were deemed not to be robust. This resulted in three classes: robust (five GCMs agree), likely (four GCMs agree) and plausible (three GCMs agree). The classification was done per grid cell for both the robustness of the trend in average drought duration and the trend in the average deficit volume. These were per grid cell combined in a bivariate classification.

\subsection{Köppen-Geiger climate classification}

The impact of changes in temperatures and precipitation patterns has been evaluated with the Köppen-Geiger climate classification (Geiger, 1954, 1961). For all combinations of RCPs and GCMs the Köppen-Geiger climate type has been determined for each cell. Climate classification has been done for each year in the period 2000-2099, where the previous 30 years were used to calculate the climatology. Changes in climate types have been evaluated for major and minor climate types, for each RCP-GCM combination separately. After the climate types have been determined for each RCPGCM combination separately, the dominant climate type for each RCP is determined from the five GCMs. Since climatology is discrete classification, no averaging was applied between the GCM climate types. The dominant climate type was used as the ensemble mean RCP climatology and used in further analyses.

\section{Results}

\subsection{Trends in future low flow regimes}

Global trends in the transient variable threshold $\left(\mathrm{VTM}_{\mathrm{t}}\right)$ were studied for each RCP separately and for the ensemble of five GCMs (Fig. 2). When $\mathrm{VTM}_{t}$ decreases, the long-term low flow regime is reduced in that location and drought characteristics were calculated against the reduced low flows. For the average over all RCP scenarios, $40-52 \%$ of the world will face decreasing low flows $\left(\mathrm{VTM}_{\mathrm{t}}\right.$ for $\left.Q_{90}\right)$. However, regional variability is large. As expected, RCP2.6 shows the smallest area with a decrease in low flows globally ( $40 \%$ of the world), while for RCP8.5 the decrease in the threshold is more severe $(52 \%)$. Differences in these trends are larger among continents and climate types (see Fig. A1 in the Appendix for the climate regions used in this study) than among the GCMs; the latter in general show high agreement on the directionality of the change. For the equatorial and warm temperate climate (A and $\mathrm{C}$ ) the low flows will decrease in $62-77 \%$ of the area, while for the snow and polar climates (D and E) the low flows will increase in $54-90 \%$ of the area (depending on RCP scenario). In these colder regions the increased low flows are mainly due to larger snowmelt and increased precipitation. However, a seasonal shift in low flows was observed for these regions where the snowmelt will occur earlier in the season under a warmer climate. This leads to reduced low flows late in summer, which was observed by the decreasing trend in July to September for most of the Northern Hemisphere (Fig. 2).

Decreased low flows were observed in South America, southern Africa, Australia and the Mediterranean area. For the summer months also North America and Europe are largely affected by a decreasing trend. As expected, the decrease in low flows is most severe for the highest emission scenario (RCP8.5), while the trends are less obvious for the 

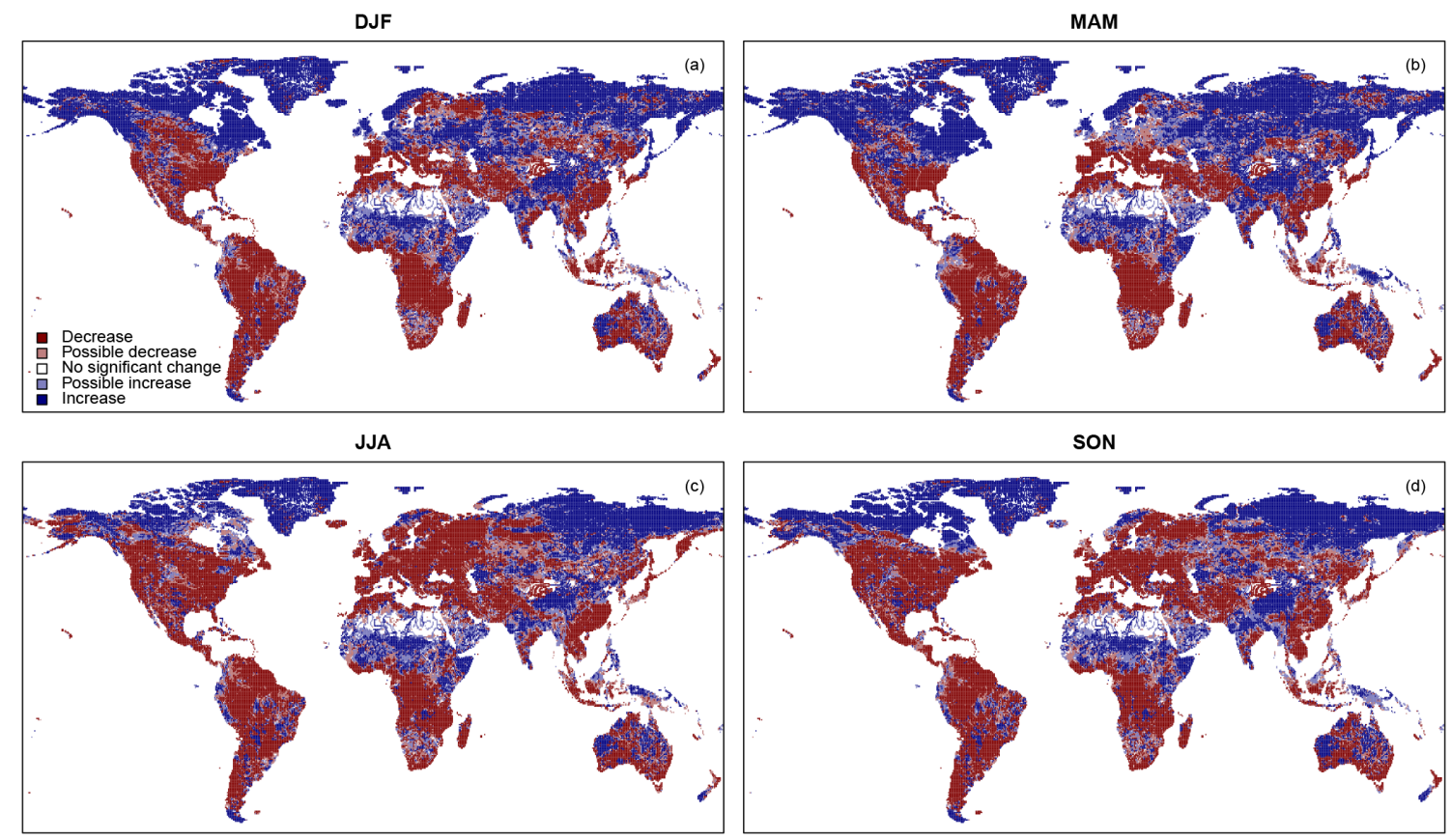

Figure 2. Average trends in the transient $Q_{90}$ threshold in the four seasons derived from simulation with PCR-GLOBWB. Trends are aggregated over 3-month periods for an ensemble of 20 members consisting of four RCPs and five GCMs. An increase or decrease is significant when over 16 ensemble members show similar trends. When over 13 ensemble members agree on the directionality of the change, the trend is deemed possible.
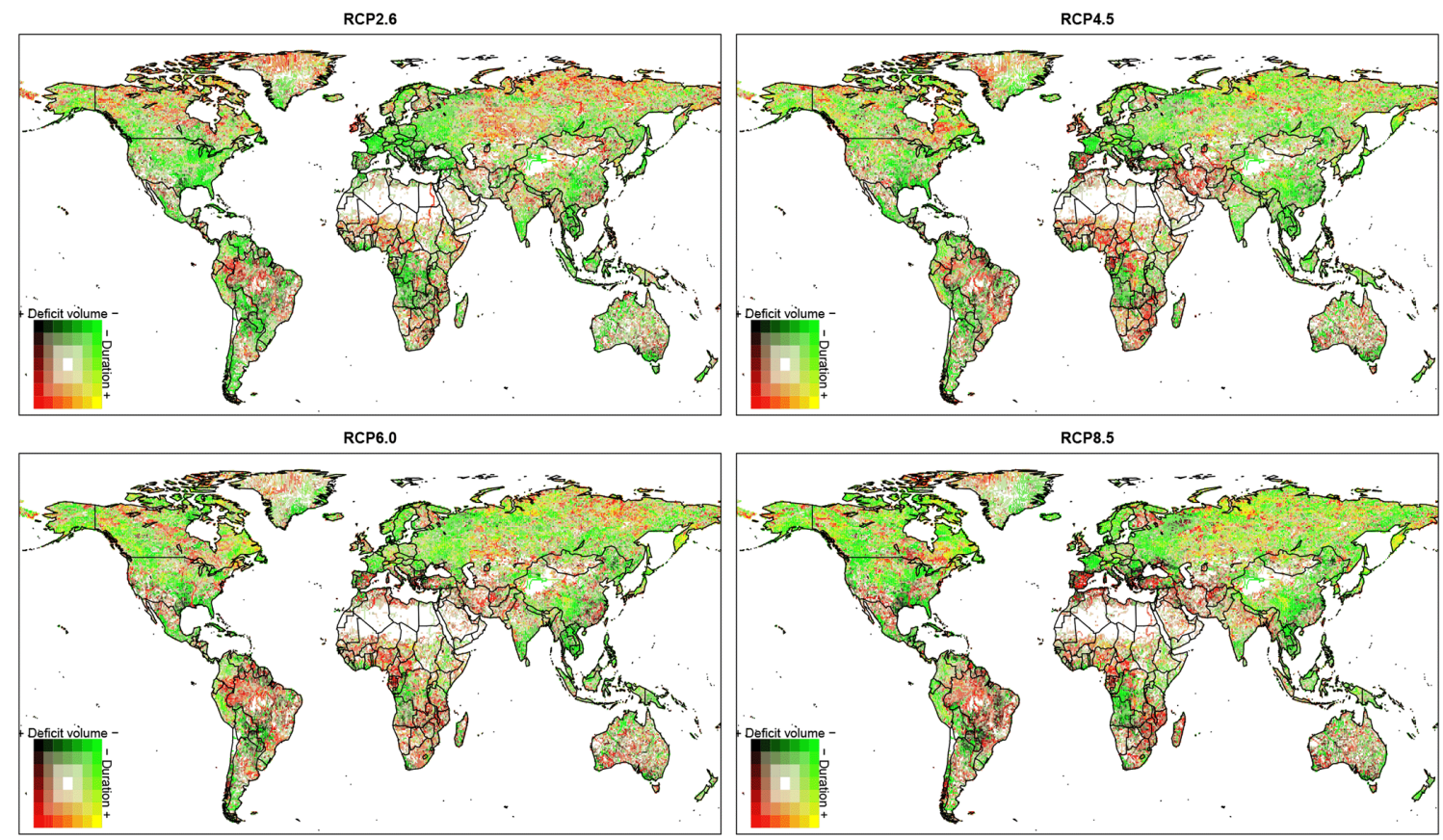

Figure 3. Average trends in drought duration and drought deficit volume, derived with a transient $Q_{90}$ threshold from discharge simulation of PCR-GLOBWB. Maps indicate the changes per RCP for an ensemble of five GCMs. Colours indicate the robustness of the trend where the darkest colours are robust (five GCMs agree), thereafter likely (four GCMs agree) and plausible (three GCMs agree). A white colour indicates areas where no drought characteristics were calculated. 


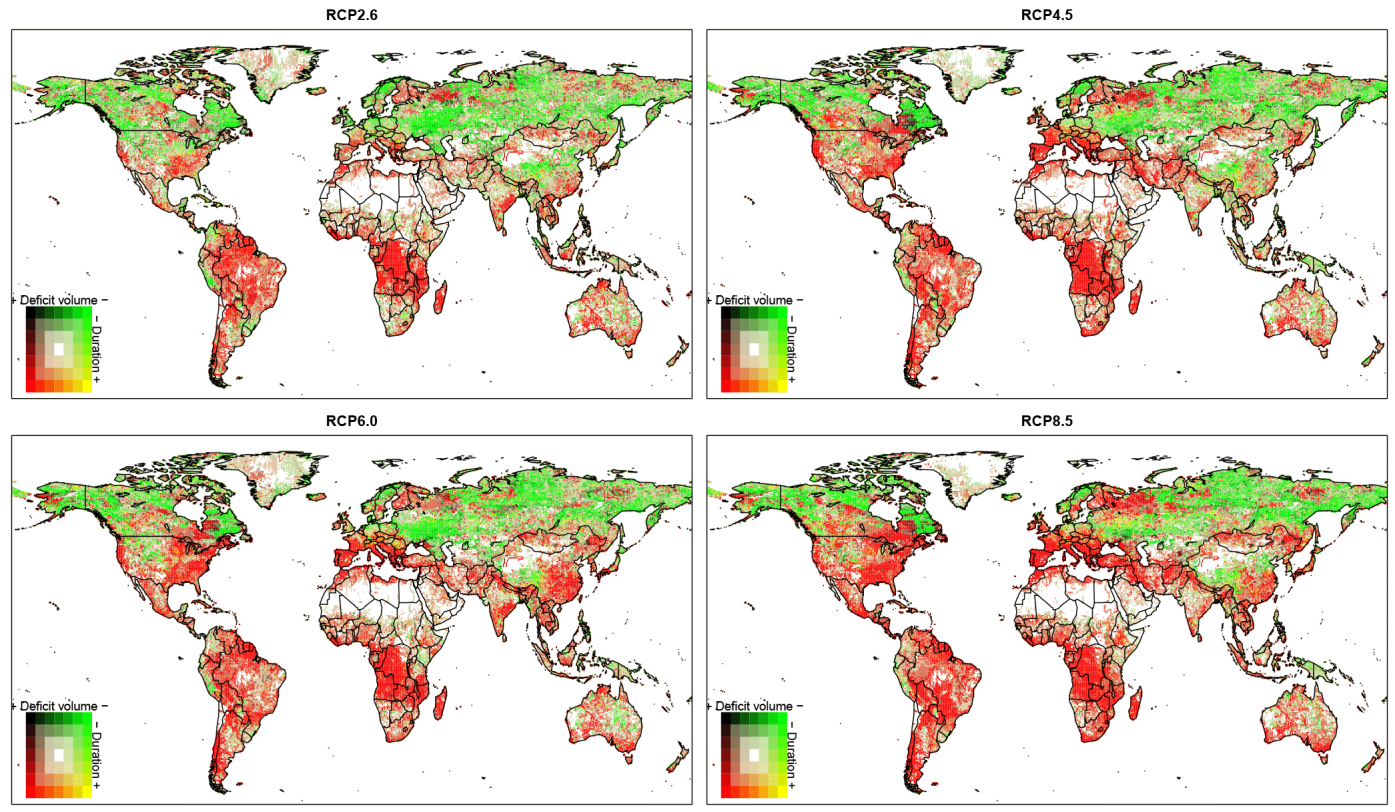

Figure 4. Average trends in drought duration and drought deficit volume, derived with the non-transient $Q_{90}$ threshold from discharge simulation of PCR-GLOBWB. Maps indicate the changes per RCP for an ensemble of five GCMs. Colours indicate the robustness of the trend where the darkest colours are robust (five GCMs agree), thereafter likely (four GCMs agree) and plausible (three GCMs agree). A white colour indicates areas where no drought characteristics were calculated.

lowest emission scenario (RCP2.6). However, all RCPs agree on where in the world the low flows will decrease (e.g decrease in variable threshold).

\subsection{Comparison in drought characteristics under a non-transient and transient hydrological regime}

Drought characteristics, i.e. drought duration and deficit volume, were calculated with the $\mathrm{VTM}_{\mathrm{t}}$ for $Q_{90}$ for all RCP scenarios and for all GCMs. Model agreement in the direction of the change is high, and distinct patterns are visible in the results (Fig. 3). Globally the agreement between the GCMs is high especially for the snow-dominated climate (D), the Mediterranean and South America. We have distinguished four possible cases in the bivariate distribution of the drought duration and the deficit volume: (i) an increase in both drought duration and deficit volume in $27 \%$ of the world (RCP8.5), (ii) increase in duration and decrease in deficit (11\%), (iii) decrease in duration and increase in deficit (17\%), and (iv) a decrease in both drought characteristics $(38 \%)$. The remaining part shows no trends of characteristics could be calculated.

Significant different trends in drought duration and deficit volume were obtained when instead of a gradually changing hydrological regime $\left(\mathrm{VTM}_{\mathrm{t}}\right)$ a stationary regime $(\mathrm{VTM})$ was assumed (Figs. 3 and 4). Large parts of the world, especially the Southern Hemisphere show significant increases in both drought duration and deficit volumes. Only the snow-affected climates show a decrease in both duration and deficit vol- ume. There is also a higher agreement that the trends in the duration and deficit volume point in the same direction than for $\mathrm{VTM}_{\mathrm{t}}$. An increase in both drought duration and deficit volume is found for $62 \%$ of the world (RCP8.5). The areas covered by the other three cases have (i) increase in duration and decrease in deficit (4\%), (ii) decrease in duration and increase in deficit $(6 \%)$, and (iii) decrease in both drought characteristics (25\%). The differences between Figs. 3 and 4 clearly show that the use of a different threshold approaches $\left(\mathrm{VTM}_{\mathrm{t}}\right.$ compared to VTM), which reflect whether a nonstationary or a stationary hydrological regime was assumed, has a significant impact on the obtained drought characteristics.

\subsection{Trends in drought characteristics under a non-stationary hydrological regime}

With the $\mathrm{VTM}_{\mathrm{t}}$ for all RCPs in large parts of the snowdominated climate a trend was found towards longer droughts, although the low flows have been increased (Figs. 2 and 3). This is partly due to the decreased length of the snow accumulation season and partly due to the shift in the snowmelt peak. Trends in the deficit volume in these areas are not so pronounced. Precipitation totals for these regions show an increase of $30-100 \mathrm{~mm}$ in annual precipitation for the period 2070-2099 compared to 1971-2000 (Warszawski et al., 2014). The annual temperature shows an increase of $2-$ $5^{\circ} \mathrm{C}$ depending on RCPs when the above-mentioned periods were compared. This confirms the observed earlier snowmelt 
Table 3. Change in global area (\%) with increased hydrological drought duration and drought deficit volume: \% change derived from 30-year averages of future (2070-2099) against reference (1971-2000) for two variable threshold methods (VTM $\mathrm{t}_{\mathrm{t}}$ and VTM) and two thresholds $Q_{80}$ and $Q_{90}$.

\begin{tabular}{lccccc}
\hline & RCP & \multicolumn{3}{c}{$\%$ of world with } \\
\cline { 3 - 6 } Drought & & \multicolumn{2}{c}{ Increased } & \multicolumn{2}{c}{ Increased } \\
identification & & \multicolumn{2}{c}{$\begin{array}{c}\text { drought duration } \\
\text { drought deficit }\end{array}$} \\
method & $Q_{80}$ & $Q_{90}$ & $Q_{80}$ & $Q_{90}$ \\
\hline Transient $\left(\right.$ VTM $\left._{\mathrm{t}}\right)$ & 2.6 & 33 & 33 & 42 & 38 \\
& 4.5 & 32 & 32 & 41 & 38 \\
& 6.0 & 35 & 34 & 43 & 40 \\
& 8.5 & 33 & 33 & 40 & 39 \\
\hline Non-transient (VTM) & 2.6 & & 46 & & 47 \\
& 4.5 & & 50 & & 51 \\
& 6.0 & & 52 & 53 \\
& 8.5 & & 54 & & 56 \\
\hline
\end{tabular}

peak and increased water availability in these regions. The snowmelt peak comes earlier in the year leading to drier soil moisture and groundwater conditions in summer.

For the Mediterranean, the savannah areas of Africa and Middle East, the increase in drought duration is larger for most scenarios (except RCP2.6). The threat is even higher due to the decrease in water availability during low flow conditions (Fig. 2). In these regions water scarcity is a known problem which could be intensified by increased drought durations. The same pattern was found for the interior of Australia, where drought duration is projected to increase and low flows to decrease. However, the impact is less due to lower population density in the region. For these drier areas, temperature rise will be limited to $0.5-3.5^{\circ} \mathrm{C}$, while annual precipitation will decrease by $35-90 \mathrm{~mm}$.

For South America the decrease in annual precipitation is limited to $12-60 \mathrm{~mm}$, while temperature increase is low (1.2$\left.3.5^{\circ} \mathrm{C}\right)$ compared to global averages $\left(1.5-4.5^{\circ} \mathrm{C}\right)$. However, drought duration in the eastern part of the continent shows a strong increase. In the wetter regions of the Amazon basin this will likely not cause significant impacts. However, the drier regions in eastern Brazil could be affected as the agricultural areas (mostly irrigation) are there.

\subsection{Köppen-Geiger climate classification}

As a result of changes in temperature and precipitation patterns, the Köppen-Geiger climate classification for a certain location may change in the 21 st century. The area and location of temperate (C) and polar (E) major climate types are most affected by the changing climate (Table 4 and Figs. A1 and A2). Global coverage of both climate types will reduce, mostly due to increasing temperatures (E) and decrease in annual precipitation (C). On the other hand the tropical (A), desert (B) and snow (D) climate types will increase in global coverage in 2070-2099 compared to 1971-2000. Regions
Table 4. Average fraction of changed major Köppen-Geiger climate types between 2000 and 2099 based on five GCMs and four RCPs.

\begin{tabular}{|c|c|c|c|c|c|}
\hline \multirow{2}{*}{$\begin{array}{l}\text { Original } \\
\text { climate type }\end{array}$} & \multicolumn{5}{|c|}{ New climate type } \\
\hline & A & B & $\mathrm{C}$ & $\mathrm{D}$ & $\mathrm{E}$ \\
\hline A & 0.975 & 0.025 & 0.000 & 0.000 & 0.000 \\
\hline $\mathrm{B}$ & 0.009 & 0.989 & 0.001 & 0.001 & 0.000 \\
\hline $\mathrm{C}$ & 0.128 & 0.091 & 0.781 & 0.000 & 0.000 \\
\hline $\mathrm{D}$ & 0.000 & 0.025 & 0.104 & 0.871 & 0.000 \\
\hline E & 0.000 & 0.027 & 0.025 & 0.343 & 0.605 \\
\hline
\end{tabular}

where changes are largest (Supplement) can be found in polar regions in the Northern Hemisphere (E to D), around the Sahara (C to B) and Gobi desert (E to B), eastern Europe (D to $\mathrm{C}$ ) and the tropics (C to A). Although not used further in this paper the changes in area and location of minor climate types are significant, especially in the temperate (C) and snow (D) minor climate types (supplementary material). The areas of the minor climate types show a shift from colder climate types (within the major climate type) to warmer climate types.

\subsection{Trends in area in drought (AID)}

The total area in drought has been calculated for $Q_{90}$ with the transient $\left(\mathrm{VTM}_{\mathrm{t}}\right)$ and the non-transient $(\mathrm{VTM})$ variable threshold approach. For the $\mathrm{VTM}_{\mathrm{t}}$ also an approach with transient adjusted climatology was applied to account for changes in the AID when a location shifts from one major climate type to another. This has been done for the globe and the five Köppen-Geiger major climate regions. The temporal evolution of the mean and uncertainty of the 20 ensemble members (five GCMs and four RCPs) are given in Fig. 5. The mean global area in drought is projected to increase 


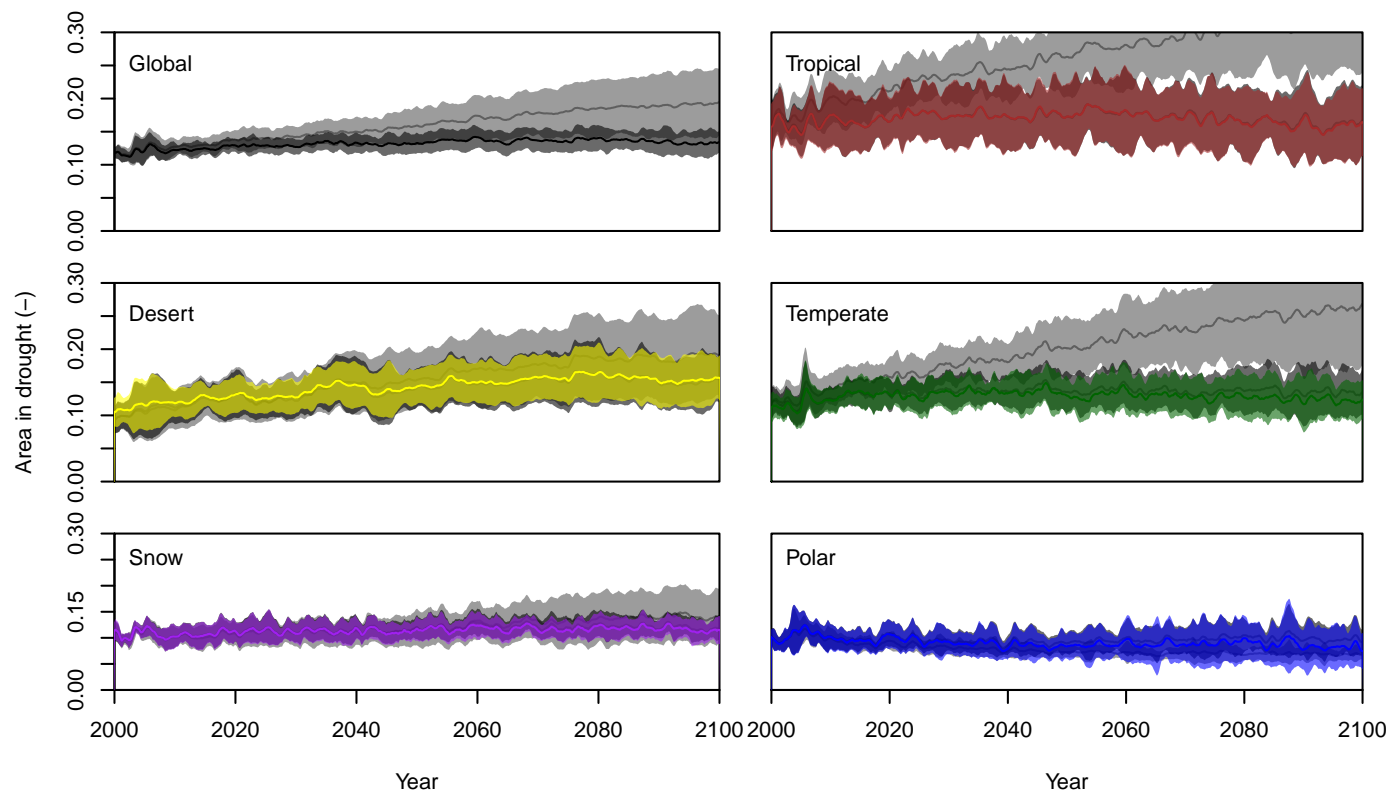

Figure 5. Projected evolution of ensemble mean area (solid line) and the spread in hydrological drought in the 21 st century derived from simulation with PCR-GLOBWB, forced by an ensemble of 20 scenarios consisting of four RCPs and five GCMs. The evolution is given for the globe and for the five major Köppen-Geiger climatic regions. The coloured lines present the evolution under a changing hydrological regime with changing climate types per cell (transient variable threshold, VTM $\mathrm{V}_{\mathrm{t}}$ ), dark grey without a changing climate per cell with the $\mathrm{VTM}_{\mathrm{t}}$ and light grey the evolution under a stationary hydrological regime (non-transient variable threshold, VTM).

from 11.7 to $13.4 \%$ under a gradually changing hydrological regime $\left(\mathrm{VTM}_{\mathrm{t}}\right)$ (Fig. 5). The uncertainty (one standard deviation) among the members by the end of the 21 st century is about $1.9 \%$. When a stationary hydrological regime was assumed (VTM), then the increase of the global area in drought was substantially larger. The mean area is expected to grow from 11.7 to $19.5 \%$. The spread among members also is projected to be substantially larger by the end of the 21 st century, i.e. $5 \%$ under a stationary hydrological regime.

The area in drought of the tropical (A) climate is expected to grow more than the global increase over the 21 st century (Fig. 5). The mean area in drought for the tropical climate will remain steady around $16.7 \%$ for the non-stationary hydrological regime $\left(\mathrm{VTM}_{\mathrm{t}}\right)$, whereas it is projected to double (16.7 to $32.6 \%$ ) by the of the century for a stationary hydrological regime (VTM). The difference between the adjusted climate type and the fixed climate types is minor at the end of the 21 st century, 16.6 compared to $16.4 \%$ (dynamic climate types). The spread among the members for the tropical climate is about $3.9 \%$ at the start of the century and is similar for the $\mathrm{VTM}_{\mathrm{t}}$ and VTM, but differences in spread are larger by the end of the century when a stationary hydrological regime $\left(\mathrm{VTM}_{\mathrm{t}}\right)$ was supposed rather than a non-stationary regime (VTM) (5.5 and $8.5 \%$, respectively).

The difference in area in drought between the $\mathrm{VTM}_{\mathrm{t}}$ and VTM approaches among the Köppen-Geiger major climates is smallest for the polar (E) climates (Fig. 5), which is caused by the increased water availability. The mean area in drought is projected to remain constant (around 10.0\%) under a non-stationary hydrological regime $\left(\mathrm{VTM}_{\mathrm{t}}\right)$, and is expected to only slightly decrease under a stationary regime (VTM) (10.2 to $6.7 \%)$. In contrast to the other climates, the spread by the end of the 21 st century is smaller when a stationary hydrological regime was supposed (i.e. $3.5 \%$ for the $\mathrm{VTM}_{\mathrm{t}}$ approach and $2.3 \%$ for the VTM approach).

The impact of a changing climate is minor as can clearly be seen from Fig. 5. Only minor differences can be found between the transient and stable climate classification results. This suggests that the impact of changes in major climate types is limited on the AID.

\section{Discussion}

\subsection{Implication of transient threshold approach}

This study uses a newly developed transient threshold, which is based on the discharge climatology of the previous 30 years. This approach has implications on how changes in drought characteristics are evaluated. For some applications the absolute water availability is important, where a particular demand of available water should be met (e.g. energy production from reservoirs or drinking water supply). However, it is questionable whether these demands could be seen as a drought. They are related to water availability and demand, which is more a matter of water scarcity, since it deals with the imbalance between the available water and the demand 
(European Union, 2007). Drought only deals with natural conditions and is not driven by any type of demand. Therefore, sectors that have a human-induced water demand are not considered with the transient threshold, and these sectors should work with a conventional fixed threshold approach. This threshold describes the water demand that should be met to prevent imbalance between demand and supply.

When looking at natural conditions and extremes in these conditions, processes like ecosystems and agriculture are included in the transient threshold approach. Climate change will induce changes in ecosystems (Fischlin et al., 2007) and require changes in agricultural management (European Union, 2009). These sectors will slowly adapt to the changes in climatology, leading to higher or lower water availability depending on where you are on Earth, and hence other crops or ecosystems. When the sectors get used to the new conditions and a below-normal water availability event occurs (i.e. drought), the effects can be significant different than without a changing climate. To illustrate, one can picture a semiarid region where agriculture is heavily impacted by waterlimiting conditions. When this region permanently receives more water (e.g. rain), this will result in a change to crops that require more water and are more productive and profitable. If this area is then hit by a drought event, the crop losses will be high due to fact that farmers have changed to the more water-demanding crops. This will result in higher productivity in the wetter, but then normal years and bigger losses in drought years, which will impact the local economy and residents. For the ecosystems a similar situation will occur, since nature will seek for an optimal situation relative to the available resources. Animals and plants that can deal with semi-arid conditions will be replaced by more successful species which fully utilize the increased availability of water resources. These animals and plants will be heavily impacted in drought conditions since they require more water and other resources, which will increase the drought vulnerability of the ecosystem. If the fixed threshold had been applied, this nature-human interaction and the availability of resources would not be taken into account and hence not captured by the analyses of future hydrological drought. For conditions that deal with a fixed demand or a demand that is not driven by water availability, this is no problem. However, in conditions where the water resources are limiting the transient threshold will give a more realistic portrayal of the potential impact of future hydrological drought.

This statement does not only apply to changes in future hydrological drought but it will also impact climate impact assessments of frequently used drought indicators like the Standardized Precipitation Index (SPI, McKee et al., 1993) and Palmer Drought Severity Index (PDSI, Palmer, 1965). For the calculation of these indicators the distribution of events is used to assess anomalies. However, the distribution of a 30-year period will change with a changing climate, and what is an anomaly in the current condition could be seen as normal in 50 years. Therefore, we propose not only to ap- ply the transient approach on drought assessments that study hydrological drought with the threshold approach. The transient approach should be applied more widely to all types of drought assessments ranging from normalized indicators like the SPI or PDSI to drought indicators like the threshold level approach. It is argued that a combined approach of transient and non-transient approach would cover all potential drought impacts and would provide a more realistic portrayal of future drought under a changing climate.

\subsection{Intercomparison with existing studies on large-scale future hydrological drought}

This study showed that in more than half of the world (about $60 \%$ of the land area) hydrological drought frequency is projected to increase by the end of the 21 st century even by considering that the hydrological regime will change. The average drought duration and deficit volume each are expected to increase in around 30 and $40 \%$ of the globe. Wanders and Van Lanen (2013) report, in their global analysis on future hydrological drought using a conceptual hydrological model and three GCMs (SRES A2 scenario), a decrease of the number of days in drought - pointing to a lower drought frequency and an increase of the average drought duration and deficit volume of the remaining drought events. The characteristics they found cannot directly be compared because these refer to magnitudes rather than to affected areas (this study), and they used another threshold $\left(Q_{80}\right)$ and the nontransient variable threshold approach (VTM, i.e. stationary hydrological regime). However, there seems to be some disagreement in at least the drought frequency. Repetition of our drought analysis with $Q_{80}$ and the VTM led to a lower area $(40 \%)$ with an increased drought frequency, whereas the area with longer drought events and larger deficit volumes increased by about 52 and $56 \%$, which indicates agreement in the direction of change of hydrological drought when the same methodology was applied.

Forzieri et al. (2014) used a large-scale hydrological model and 12 GCMs (SRES A1B scenario) to conclude that low flows in the 2080s are expected to become more extreme in large parts of Europe during the period without frost. Exceptions are Scandinavia, the Baltic countries and northern Russia. They used the $Q_{80}$ and the VTM for their analysis. In our study the area in Europe with a higher future drought frequency varied from about 75 to $85 \%$ (RCPs 6.0 and 8.5), which seems to be in line with their study. The area with a higher future average drought deficit volume, however, is about $30-35 \%$ (see also Fig. 3), which appears to disagree with their conclusion. Repetition of our drought analysis with $Q_{80}$ and the VTM led to a larger area (55-70\%) with an increased deficit volume, which agrees more with their outcome.

Prudhomme et al. (2014) explored future hydrological drought using seven global hydrological models (GHMs) and the same GCMs and RCPs as this study. They show that the 
increase of the global area in drought depends on the RCP, models (GCM, GHM, in particular if the $\mathrm{CO}_{2}$ effect is included) and the temporal scale (annual, season). The mean increase varies from about $4 \%$ under RCP2.6 to $13 \%$ under RCP8.5. The spread in increase is large with a maximum increase of about $25 \%$. They used the $Q_{90}$ and the VTM for their analysis. Their results correspond well with our study, but only when using a non-stationary hydrological regime (Fig. 4). Clearly, the increase of global area in hydrological drought is smaller if the variable threshold is based on a transient hydrological regime $\left(\mathrm{VTM}_{\mathrm{t}}\right)$.

Intercomparison of future hydrological drought from this study against existing similar studies showed that the outcome points more or less in the same direction, if the same methodology is applied. However, it also shows the large influence of assumptions on projected drought characteristics, such as a transient variable threshold derived from a changing hydrological regime that is introduced in this study vs. the non-transient variable threshold derived from a stationary hydrological regime that has been used in the few existing future hydrological drought studies so far.

Van Huijgevoort et al. (2014) describe that it is not straightforward to determine future hydrological drought with the VTM derived from historical observations. This can lead to unintended future drought events (short-lived, very high deficit volume) for climates and hydrological systems with a sharp rise in the hydrograph (e.g. cold climates with pronounced snowmelt, monsoon climates) that will face a regime shift. The $\mathrm{VTM}_{t}$ method proposed in this study implicitly handles this impact of a regime shift.

When the transient threshold decreases (Fig. 2) it implies that the low flows are reduced in that location. When these reduced low flows coincide with an increase in drought duration and deficit volume, this will have a large impact on the water availability under drought (15\% of the world). This poses enormous challenges to society and nature to adapt, especially in developing countries, which usually are very vulnerable.

\subsection{Uncertainty}

Differences between projected temperature and precipitation with GCMs and RCPs used (Tables 1 and 2) are large (e.g. Warszawski et al., 2014). Clearly, these differences influence future hydrological drought, as illustrated by Prudhomme et al. (2014) and Wanders and Van Lanen (2013). The spread in the projected temporal evolution of the global area in hydrological drought, as shown in Fig. 5, also illustrates the impact of different climate drivers. In particular, the spread is large for the tropical climate and desert climate. Prudhomme et al. (2014) conclude that the model structure of the hydrological models substantially contributes to uncertainty in future hydrological drought, particularly if the rather hard predictable response of plants to a changing $\mathrm{CO}_{2}$ concentration (i.e. $\mathrm{CO}_{2}$ effect) is implemented. The PCR-GLOBWB model used in this study is one of the seven hydrological models that contributed to the ISI-MIP project (Warszawski et al., 2014); the $\mathrm{CO}_{2}$ effect is not included. The results found in Prudhomme et al. (2014) suggest that the PCR-GLOBWB model is not an outlier among the ensemble of GHMs. PCRGLOBWB does not include the $\mathrm{CO}_{2}$ effect, which reduces the impact of model structure on the hydrological simulations. Furthermore, the model has proven to reasonably capture hydrological characteristics (Wada et al., 2013) and the hydrological regime in general (Van Beek et al., 2011). The results from these studies (Van Beek et al., 2011; Prudhomme et al., 2014; Wada et al., 2013) suggest that PCR-GLOBWB is a suitable model to use for a more detailed study into changes of hydrological drought characteristics. Moreover, the focus of this study is on the impact of the $\mathrm{VTM}_{t}$ on the drought detection and less focussed on the specific changes in future hydrological drought. Given the performance of PCR-GLOBWB and the objective of this study, the authors believe that the single model approach with PCR-GLOBWB can be used with confidence to study the impact of the $\mathrm{VTM}_{t}$ on future hydrological drought.

Hydrological model error is obscured by the climate bias from GCMs, yet it is manifest for the drier regions of the world where runoff tends to be overestimated. Model errors in these areas concern the runoff-generating mechanisms that are extremely difficult to capture (e.g. Döll et al., 2003) and the underestimation of losses due to evapotranspiration and reinfiltration or withdrawals or diversions along the river channel (e.g. Nile and Yellow River). Water withdrawals and diversions may also affect performance for rivers in temperate regions such as the Mississippi and the Yangtze River, which are not accounted for in the model. However, the improvement gained from including water withdrawals is rather limited and uncertainty in climate forcing dominates the model performance and errors (Wada et al., 2014).

Generally, the model performance in terms of river discharge increases with catchment size. This is logical for a macro-scale hydrological model that is unable to reproduce the fine details that govern runoff generation in the smaller catchments. Model errors are more salient when looking at the temporal performance of the model. Errors in the timing of the discharge can be attributed to the constant floodplain extent and the consequent errors in the resistance that is experienced by the flood wave. For the Arctic and snowinfluenced temperate rivers, the timing of the snowmelt is the main source for the uncertainty in temporal shifts in the regime curves. These errors and model uncertainties are rather common in global hydrological models and are not limited to the PCR-GLOBWB that has been used in this study.

Another source of uncertainty is the drought identification methodology that should be defined by the droughtimpacted sectors. These sectors determine the magnitude of the threshold level to be used (e.g. $Q_{80}$ instead of $Q_{90}$ ) and whether a fixed threshold (constant through the whole pe- 
riod) or a variable threshold method should be applied. Similarly, these sectors determine whether a $\mathrm{VTM}_{t}$ for the variable threshold approach should be chosen for the assessment of future drought that considers a gradually changing hydrological regime in the future or that a VTM should be taken that is based on a stationary hydrological regime derived from historical observations. Table 3 shows that the global area with increased average hydrological drought duration is hardly affected by the selection of the magnitude of the threshold level (maximum difference in \% change is $1 \%)$. Differences for the average deficit volume are slightly larger (maximum difference in \% change of global area with increased deficit volume is $4 \%$ ). Differences are substantially larger regardless of whether the $\mathrm{VTM}_{t}$ or the VTM was applied. The difference in change of area in hydrological drought with increased drought duration is $13 \%$ for RCP2.6 and $18-19 \%$ for the other RCPs. The difference in change for the drought deficit volume is $9 \%$ for RCP2.6, $13 \%$ for RCP4.5 and 6.0, and $17 \%$ for RCP8.5. As expected, it appears that the difference in projected change of global area in hydrological drought between the two variable threshold methods is larger for the more extreme RCPs.

\section{Conclusions}

In this study future hydrological drought that considers adaptation to a gradually changing hydrological regime has been studied. An ensemble of five general circulation models (GCMs) and four representative concentration pathways (RCPs) has been used as meteorological forcing for the global hydrological model PCR-GLOBWB. Daily discharge has been simulated for the period 1971-2099, and drought in discharge was detected using two threshold level approaches. The conventionally applied variable threshold (VTM) was calculated by deriving the threshold from the period 19712000, and subsequently the VTM was used for the period 2000-2099 to identify future drought characteristics (stationary approach). As an alternative, the transient variable threshold $\left(\mathrm{VTM}_{\mathrm{t}}\right)$ was proposed, which is based on the discharge values of the previous 30 years, where the threshold will vary over time (non-stationary approach). The $\mathrm{VTM}_{\mathrm{t}}$ reflects changes in the hydrological regime as response to climate change. The $\mathrm{VTM}_{t}$ is supposed to provide more realistic future hydrological drought characteristics when the impacted sectors are able to adapt to gradual changes in the hydrological regime. The $Q_{90}$ (discharge that is equalled or exceeded $90 \%$ of the time) has been used both for the VTM and $\mathrm{VTM}_{\mathrm{t}}$.
Results based on the $\mathrm{VTM}_{\mathrm{t}}$ show that low flows are projected to become lower in $40-52 \%$ of the world (dependent on the RCP). In the equatorial and warm temperate (A and C) climates the low flows will decrease in $62-77 \%$ of the area, while for the snow and polar (D and E) climates the low flows will decrease in 10-46\% of the area. The small decrease in low flows for the snow-affected climates is mainly due to increased precipitation leading to higher low flows. A regime shift was also found where snowmelt will occur earlier in the season due to higher temperatures leading to drier conditions during the summer. Droughts were identified relative to these altered low flow conditions when applying the $\mathrm{VTM}_{\mathrm{t}}$.

Future hydrological drought characteristics strongly depend on whether the impact of adaptation to a gradually changing hydrological regime due to climate change is considered $\left(\mathrm{VTM}_{\mathrm{t}}\right)$ or not $(\mathrm{VTM})$. The global area with an increase of both duration and deficit volume will be only $27 \%$ (RCP8.5) by the end of the 21st century by using the $\mathrm{VTM}_{t}$, whereas this is substantially larger $(62 \%)$ when the VTM is applied. The area with a decrease of both the duration and the deficit volume is larger when the $\mathrm{VTM}_{\mathrm{t}}$ was used rather than the VTM (38 and $25 \%$, respectively). The global area in drought is also strongly affected by whether the $\mathrm{VTM}_{\mathrm{t}}$ or VTM is applied. The mean global area with drought in discharge is projected to increase by only a few per cent (11.7 to $13.4 \%$ ) when using the $\mathrm{VTM}_{\mathrm{t}}$, but it is expected to become about $20 \%$ (RCP8.5) when the stationary approach is applied (VTM). The spread in projected areal increase among ensemble members also is substantially smaller when the $\mathrm{VTM}_{t}$ is used instead of the VTM.

Results show that, although the $\mathrm{VTM}_{\mathrm{t}}$ has been used, drought duration and deficit volume is expected to increase in large parts of South America, southern Africa and the Mediterranean. In $15 \%$ of the world a negative trend in low flows is found in combination with an increase in drought duration and deficit volume, which points at a likelihood of severe future water stress.

The study demonstrates that an alternative way of identifying hydrological drought that considers adaptation to an altered hydrological regime caused by climate change has a significant influence on future hydrological drought characteristics. For sectors that can deal with gradual changes in the hydrological regime, the transient variable threshold $\left(\mathrm{VTM}_{\mathrm{t}}\right)$ is an alternative approach to calculate drought characteristics. 
Appendix A

Koeppen-Geiger climate types 2000
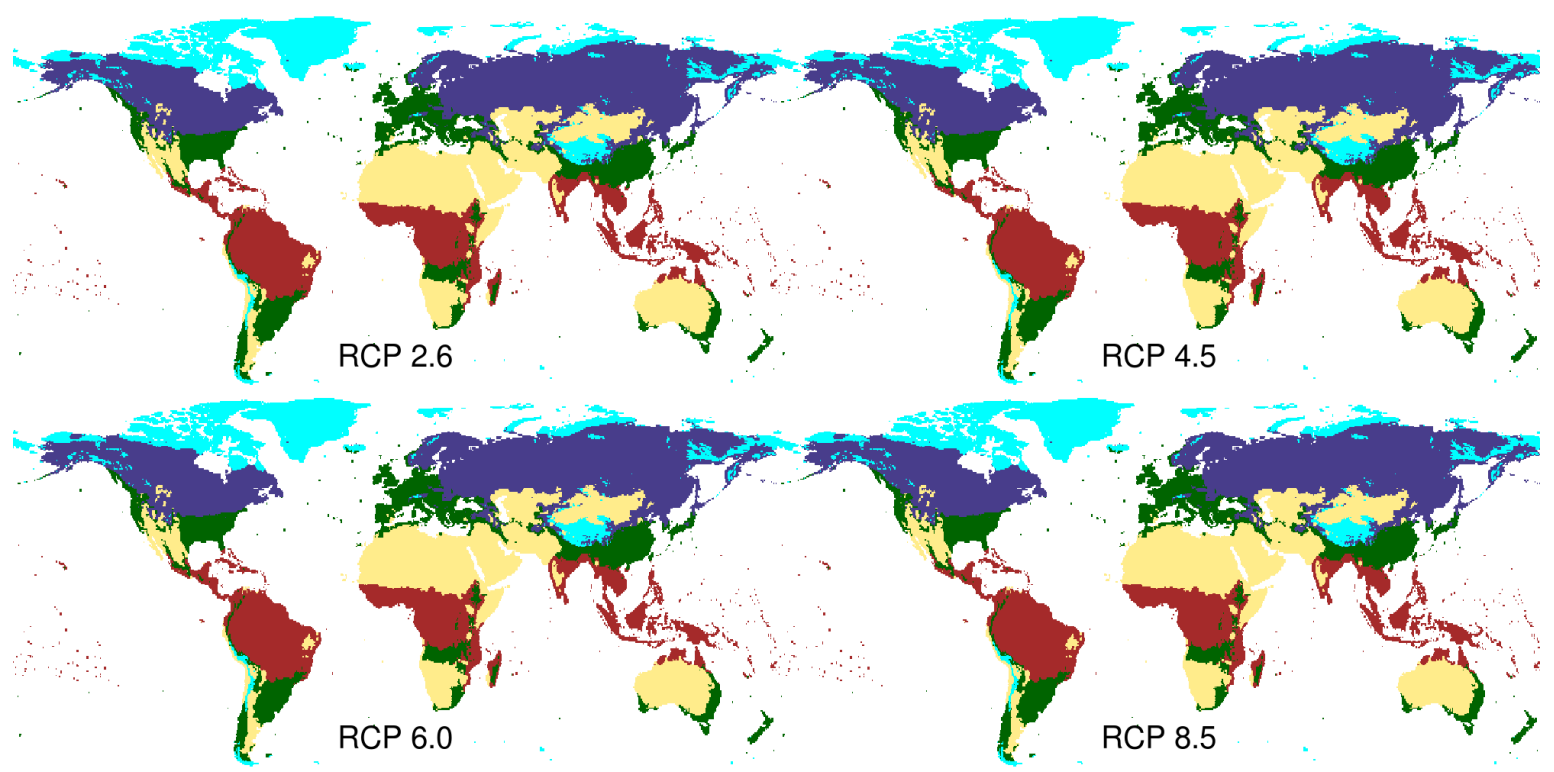

Tropical

Desert

Temperate

Snow

Polar

Figure A1. Global map of Köppen-Geiger climate types for 2000.

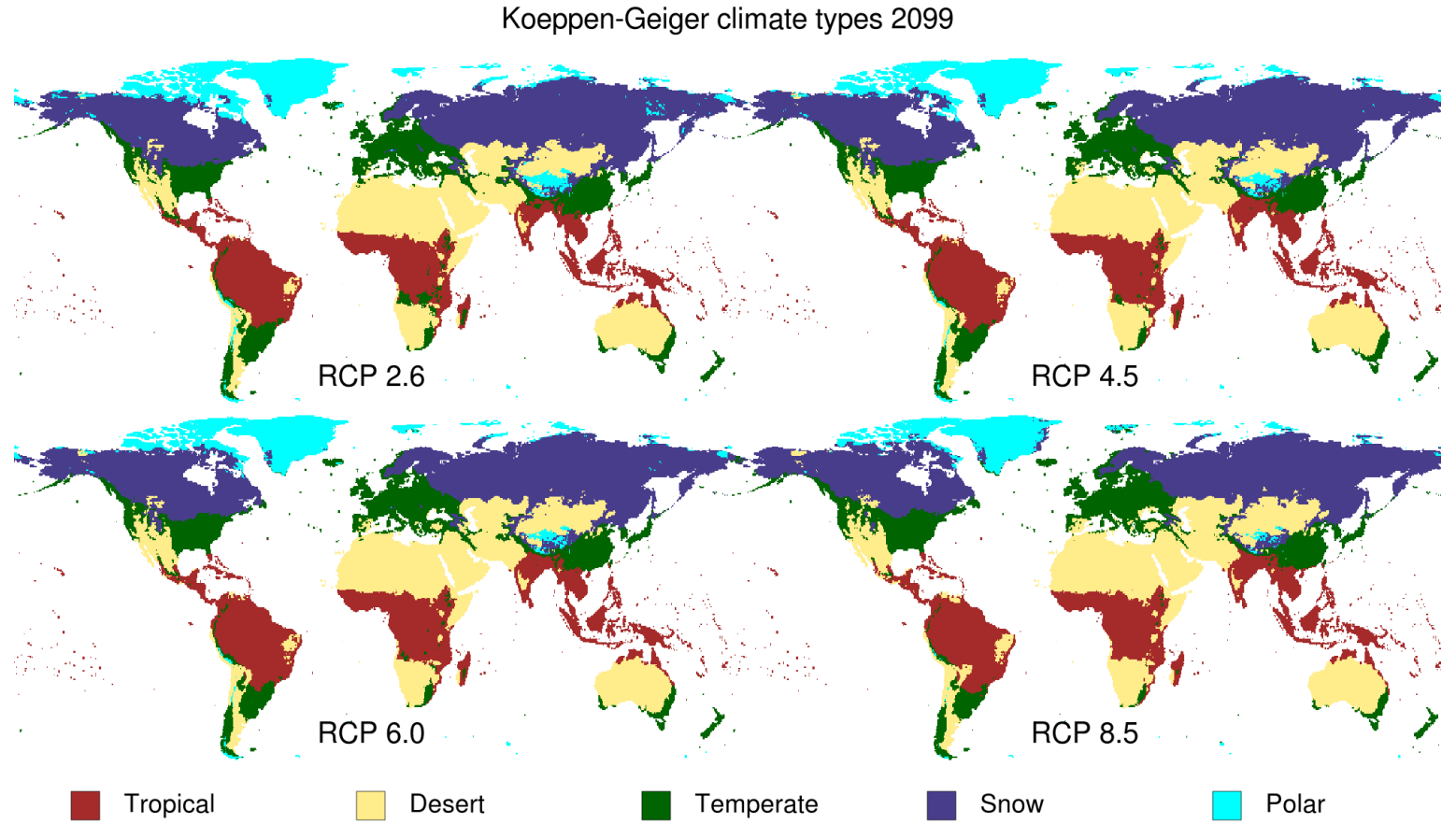

Figure A2. Global map of Köppen-Geiger climate types for 2099. 


\section{The Supplement related to this article is available online at doi:10.5194/esd-6-1-2015-supplement.}

Acknowledgements. N. Wanders was funded by a grant from the user support program Space Research of NWO (contract number NWO GO-AO/30). This work has been supported by the framework of ISI-MIP funded by the German Federal Ministry of Education and Research (BMBF) (project-funding reference number: 01LS1201A). This research was undertaken as part of the European Union FP7 Collaborative project DROUGHT-R\&SPI (grant 282769, H.A.J. van Lanen). The research is part of the programme of the Wageningen Institute for Environment and Climate Research (WIMEK-SENSE), and it supports the work of the UNESCO-IHP VII FRIEND-Water programme (H. A. J. van Lanen). We thank two anonymous reviewers for their constructive comments, which helped to improve the manuscript.

Edited by: M. Floerke

\section{References}

Arguez, A. and Vose, R. S.: The Definition of the Standard WMO Climate Normal: The Key to Deriving Alternative Climate Normals, B. Am. Meteorol. Soc., 92, 699-704, doi:10.1175/2010BAMS2955.1, 2010.

Bergström, S.: The HBV model, in: Computer Models of Watershed Hydrology, Water Resour. Publ., Highlands Ranch, Colorado, USA, 1995.

Bourzac, K.: Water: The flow of technology, Nature, 501, S4-S6, doi:10.1038/501S4a, 2013.

Burke, E. J., Brown, S. J., and Christidis, N.: Modeling the Recent Evolution of Global Drought and Projections for the TwentyFirst Century with the Hadley Centre Climate Model, J. Hydrometeor, 7, 1113-1125, doi:10.1175/JHM544.1, 2006.

Dai, A.: Increasing drought under global warming in observations and models, Nat. Clim. Change, 3, 52-58, doi:10.1038/nclimate1633, 2013.

Döll, P., Kaspar, F., and Lehner, B.: A global hydrological model for deriving water availability indicators: model tuning and validation, J. Hydrol., 270, 105-134, doi:10.1016/S00221694(02)00283-4, 2003

EEA: Mapping the impact of natural hazards and technological accidents in Europe. An overview of the last decade, Tech. Rep. 13/2010, EEA, Copenhagen, 2010.

European Union: Addressing the Challenge of Water Scarcity and Droughts in the European Union, Communication from the Commission to the European Parliament and the Council, European Commission, DG Environment, Brussels, 2007.

European Union: Adapting to climate change: Towards a European framework for action, White Paper, 2009.

Fischlin, A., Midgley, G., Price, J., Leemans, R., Gopal, B., Turley, C., Rounsevell, M., Dube, O., Tarazona, J., and Velichko, A.: Climate Change 2007: Impacts, Adaptation and Vulnerability. Contribution of Working Group II to the Fourth Assessment Report of the Intergovernmental Panel on Climate Change, chap. Ecosystems, their properties, goods, and services, 211272, Cambridge University Press, Cambridge, 2007.
Fleig, A. K., Tallaksen, L. M., Hisdal, H., and Demuth, S.: A global evaluation of streamflow drought characteristics, Hydrol. Earth Syst. Sci., 10, 535-552, doi:10.5194/hess-10-535-2006, 2006.

Forzieri, G., Feyen, L., Rojas, R., Flörke, M., Wimmer, F., and Bianchi, A.: Ensemble projections of future streamflow droughts in Europe, Hydrol. Earth Syst. Sci., 18, 85-108, doi:10.5194/hess-18-85-2014, 2014.

Geiger, R.: Landolt-Börnstein, in: Zahlenwerte und Funktionen aus Physik, Chemie, Astronomie, Geophysik un Technik, Vol. 3 of alte Serie, Chap. Klassifikation der Klimate nach W. Köppen, 603-607, Springer, Berlin, 1954.

Geiger, R.: Überarbeitete Neuausgabe von Geiger, R.: KöppenGeiger / Klima der Erde, Wandkarte 1:16 Mill., klett-Perthes, Gotha, 1961.

Hagemann, S. and Gates, L. D.: Improving a sub-grid runoff parameterization scheme for climate models by the use of high resolution data derived from satellite observations, Clim. Dynam., 21, 349-359, doi:10.1007/s00382-003-0349-x, 2003.

Hamon, W. R.: Computation of direct runoff amounts from storm rainfall, IAHS Publucation, 63, 52-62, 1963.

Hempel, S., Frieler, K., Warszawski, L., Schewe, J., and Piontek, F.: A trend-preserving bias correction - the ISI-MIP approach, Earth Syst. Dynam., 4, 219-236, doi:10.5194/esd-4-219-2013, 2013.

Hisdal, H., Tallaksen, L., Clausen, B., Peters, E., and Gustard, A.: Hydrological Drought Characteristics, in: Hydrological Drought: Processes and estimation methods for streamflow and groundwater, edited by: Tallaksen, L. and Van Lanen, H., no. 48 in Development in Water Science, 139-198, Elsevier, 2004.

Kraijenhof van de Leur, D.: Some effects of the unsaturated zone on nonsteady free-surface groundwater flow as studied in a sealed granular model, J. Geophys. Res.-Space, 67, 4347-4362, 1962.

McKee, T., Doesken, N., and Kleist, J.: The relationship of drought frequency and duration to time scales, in: Eighth Conference on Applied Climatology, 17-22 January, Anaheim, California, 1993.

Orlowsky, B. and Seneviratne, S. I.: Elusive drought: uncertainty in observed trends and short- and long-term CMIP5 projections, Hydrol. Earth Syst. Sci., 17, 1765-1781, doi:10.5194/hess-171765-2013, 2013.

Palmer, W.: Meteorological drought, US Weather Bureau Research Paper, No. 45, 58 pp., 1965.

Parry, S., Prudhomme, C., Hannaford, J., and Lloyd-Hughes, B.: Examining the spatio-temporal evolution and characteristics of large-scale European droughts, in: Role of Hydrology in Managing Consequences of a Changing Global Environment. Proceedings of the BHS Third International Symposium, edited by: Kirby, C., 135-142, British Hydrological Society, 2010.

Prudhomme, C., Giuntoli, I., Robinson, E. L., Clark, D. B., Arnell, N. W., Dankers, R., Fekete, B. M., Franssen, W., Gerten, D., Gosling, S. N., Hagemann, S., Hannah, D. M., Kim, H., Masaki, Y., Satoh, Y., Stacke, T., Wada, Y., and Wisser, D.: Hydrological droughts in the 21st century, hotspots and uncertainties from a global multimodel ensemble experiment, Proc. Natl. Acad. Sci., 111, 3262-3267, doi:10.1073/pnas.1222473110, 2014.

Romm, J.: Desertification: The next dust bowl, Nature, 478, 450451, doi:10.1038/478450a, 2011. 
Seneviratne, S. I., Nicholls, N., Easterling, D., Goodess, C. M., Kanae, S., Kossin, J., Luo, Y., Marengo, J., McInnes, K., Rahimi, M., Reichstein, M., Sorteberg, A., Vera, C., and Zhang, X.: Changes in climate extremes and their impacts on the natural physical environment, Chap. A Special Report of Working Groups I and II of the Intergovernmental Panel on Climate Change (IPCC), 109-230, Cambridge University Press, Cambridge, UK, and New York, NY, USA, 2012.

Sheffield, J. and Wood, E.: Projected changes in drought occurrence under future global warming from multi-model, multiscenario, IPCC AR4 simulations, Clim. Dynam., 31, 79-105, doi:10.1007/s00382-007-0340-z, 2008.

Sheffield, J. and Wood, E. F.: Drought: past problems and future scenarios, Earthscan, London, 2011.

Sheffield, J., Wood, E. F., and Roderick, M. L.: Little change in global drought over the past 60 years, Nature, 491, 435-438, doi:10.1038/nature11575, 2012.

Sida, L., Gray, B., and Asmare, E.: Real-time evaluation of the humanitarian response to the Horn of African drought crises, Tech. Rep., Inter-Agency Standing Committee, 2012.

Tallaksen, L. and Van Lanen, H.: Hydrological Drought: Processes and estimation methods for streamflow and groundwater, no. 48 in Development in water science, Elsevier, 2004.

Tallaksen, L. M., Madsen, H., and Clausen, B.: On the definition and modelling of streamflow drought duration and deficit volume, Hydrol. Scie., 42, 15-33, 1997.

Trenberth, K. E., Dai, A., van der Schrier, G., Jones, P. D., Barichivich, J., Briffa, K. R., and Sheffield, J.: Global warming and changes in drought, Nat. Clim. Change, 4, 17-22, doi:10.1038/nclimate2067, 2014.

United Nations: Humanitarian Requirements for the Horn of Africa Drought 2011., Tech. Rep., Office for the Coordination of Humanitarian Affairs (OCHA), New York and Geneva, 2011.

Van Beek, L. P. H., Wada, Y., and Bierkens, M. F. P.: Global monthly water stress: I. Water balance and water availability, Water Resour Res, 47, W07517, doi:10.1029/2010WR009791, 2011.

Van Huijgevoort, M. H. J., Van Lanen, H. A. J., Teuling, A. J., and Uijlenhoet, R.: Identification of changes in hydrological drought characteristics from a multi-GCM driven ensemble constrained by observed discharge, J. Hydrol., 512, 421-434, doi:10.1016/j.jhydrol.2014.02.060, 2014.

Van Lanen, H. A. J., Wanders, N., Tallaksen, L. M., and Van Loon, A. F.: Hydrological drought across the world: impact of climate and physical catchment structure, Hydrol. Earth Syst. Sci., 17, 1715-1732, doi:10.5194/hess-17-1715-2013, 2013.

Van Loon, A. F. and Van Lanen, H. A. J.: A process-based typology of hydrological drought, Hydrol. Earth Syst. Sci., 16, 19151946, doi:10.5194/hess-16-1915-2012, 2012.

Van Loon, A. F., Tijdeman, E., Wanders, N., Van Lanen, H. A. J., Teuling, A. J., and Uijlenhoet, R.: How climate seasonality modifies drought duration and deficit, J. Geophys. Res.-Atmos., 119, 4640-4656, doi:10.1002/2013JD020383, 2014.

Van Vliet, M. T. H., Yearsley, J. R., Ludwig, F., Vogele, S., Lettenmaier, D. P., and Kabat, P.: Vulnerability of US and European electricity supply to climate change, Nat. Clim. Change, 2, 676681, doi:10.1038/nclimate1546, 2012.
Van Vuuren, P., Edmonds, J., Kainuma, M., Riahi, K., Thomson, A., Hibbard, K., Hurtt, G., Kram, T., Krey, V., Lamarque, J.F., Masui, T., Meinshausen, M., Nakicenovic, N., Smith, S., and Rose, S.: The representative concentration pathways: an overview, Clim. Change, 109, 5-31, doi:10.1007/s10584-0110148-z, 2011.

Vidal, J.-P., Martin, E., Kitova, N., Najac, J., and Soubeyroux, J.M.: Evolution of spatio-temporal drought characteristics: validation, projections and effect of adaptation scenarios, Hydrol. Earth Syst. Sci., 16, 2935-2955, doi:10.5194/hess-16-29352012, 2012.

Vörösmarty, C. J., Fekete, B. M., Meybeck, M., and Lammers, R. B.: A simulated topological network representing the global system of rivers at 30-minute spatial resolution (STN-30), Global Biogeochem. Cy., 14, 599-621, 2000.

Wada, Y., van Beek, L. P. H., van Kempen, C. M., Reckman, J. W. T. M., Vasak, S., and Bierkens, M. F. P.: Global depletion of groundwater resources, Geophys. Res. Lett., 37, L20402, doi:10.1029/2010GL044571, 2010.

Wada, Y., van Beek, L. P. H., and Bierkens, M. F. P.: Nonsustainable groundwater sustaining irrigation: A global assessment, Water Resour. Res., 48, W00L06, doi:10.1029/2011WR010562, 2012.

Wada, Y., van Beek, L. P. H., Wanders, N., and Bierkens, M. F. P.: Human water consumption intensifies hydrological drought worldwide, Environ. Res. Lett., 8, 034036, doi:10.1088/17489326/8/3/034036, 2013.

Wada, Y., Wisser, D., and Bierkens, M. F. P.: Global modeling of withdrawal, allocation and consumptive use of surface water and groundwater resources, Earth Syst. Dynam., 5, 15-40, doi:10.5194/esd-5-15-2014, 2014.

Wanders, N. and Van Lanen, H. A. J.: Future hydrological drought across climate regions around the world modelled with a synthetic hydrological modelling approach forced by three General Circulation Models, Nat. Hazards Earth Syst. Sci. Discuss, 1, 7701-7738, doi:10.5194/nhessd-1-7701-2013, 2013.

Wanders, N. and Wada, Y.: Human and climate impacts on the 21 st century hydrological drought, J. Hydrol., doi:10.1016/j.jhydrol.2014.10.047, in press, 2014.

Warszawski, L., Frieler, K., Huber, V., Piontek, F., Serdeczny, O., and Schewe, J.: The Inter-Sectoral Impact Model Intercomparison Project (ISI-MIP): Project framework, Proc. Natl. Acad. Sci., 111, 3228-3232, doi:10.1073/pnas.1312330110, 2014.

Wilhite, D.: Drought: A global assessment, Routledge, London, New York, ISBN: 0-415-16834-1, 2000.

World Meteorological Organization: The Role of Climatological Normals in a Changing Climate, wCDMP-No. 61, WMOTD/No. 1377, 2007.

Yevjevich, V.: An objective approach to definition and investigation of continental hydrological droughts, Hydrology papers, 23, Colorado state university, Fort Collins, USA, 1967. 